\title{
Alterations IN YelLOWSTONE LAKE NITROGEN CYCLING DUE TO INTRODUCED LAKE TROUT AND SUBSEQUENT DECLINE OF YELLOWSTONE CUTTHROAT TROUT
}

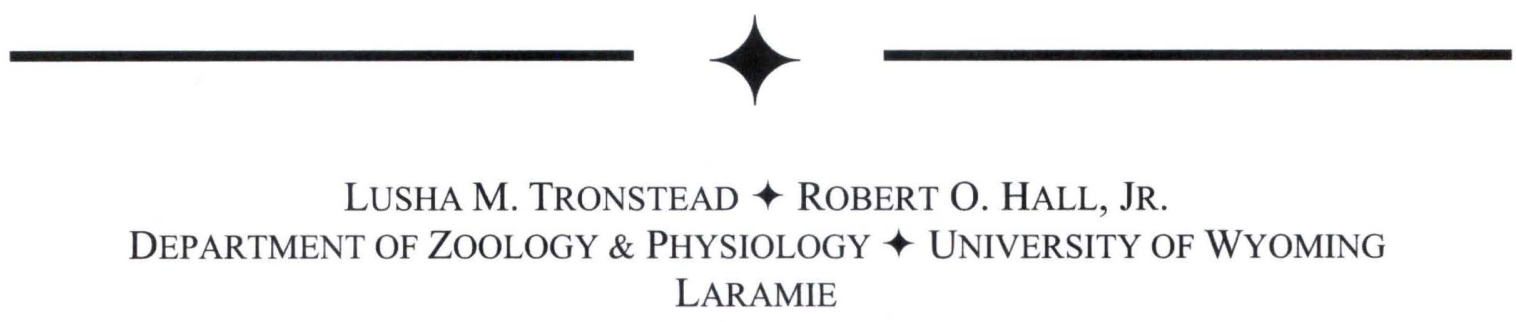

$\downarrow$ Abstract

Invasive species may alter processes by indirectly affecting other species in the ecosystem, but indirect affects are difficult to measure and often pre-invasion data were not collected. However, models may be used with empirical relationships and available past data to reconstruct past processes. The introduction of lake trout (Salvelinus namaycush) in Yellowstone Lake may have indirect effects on nitrogen cycling and provide an opportunity to study the effects of an invasive species on lake processes. To estimate how lake trout altered nitrogen cycling in Yellowstone Lake, we measured ammonium $\left(\mathrm{NH}_{4}{ }^{+}\right)$uptake by phytoplankton in 2005 and estimate past $\mathrm{NH}_{4}{ }^{+}$ uptake using empirical relationships and past data. Using ${ }^{15} \mathrm{~N}$, we measured phytoplankton uptake in 4 areas of Yellowstone Lake. Phytoplankton demanded $4.9 \mathrm{mg} \mathrm{N} \mathrm{m} \mathrm{mr}^{-1}$ during the ice-free season of 2005. Uptake was higher at warmer water temperatures and shallower Secchi disk depths (measure of phytoplankton biomass). Using relationships among uptake, water temperature, and Secchi disk depth, we estimated phytoplankton uptake in the past based on historical Secchi disk depths and water temperatures. Water temperatures have increased $0.29^{\circ} \mathrm{C} /$ decade and Secchi disk depths became $0.53 \mathrm{~m} /$ decade deeper over the past 30 years. Using our multiple regression model, phytoplankton uptake did not change between 1976 and 2006. The interaction between warmer water temperatures and deeper Secchi disk depths (a sparser algal assemblage) cancelled out resulting in no changed in modeled uptake. Therefore, when estimating past processes, we should use multiple predictors.

\section{$\downarrow$ INTRODUCTION}

The introduction of invasive species and climate change threaten to alter ecosystems around the globe; however, many times their effects on ecosystems are unknown, but potentially large. Invasive species threaten to homogenize biota (Rahel 2000), alter biodiversity (Lonsdale 1999, Randall 2000), change interactions among species (Ruzycki et al. 2003), and modify ecosystem structure and function (Tronstad 2008). Climate change was single handedly responsible for changes in species ranges (Parmesan and Yohe 2003), earlier annual events (Winder and Schindler 2004), and temperatures (Walther et al. 2002). However, the combined effects of invasive species and climate changed have rarely been investigated.

Of particular concern is the interaction between climate change and invasive species (Dukes and Mooney 1999, Stachowicz et al. 2002). Predicting the response of ecosystems to a single stressor is complicated, and invasive species and climate change may interact in 
surprising ways. Together invasive species and climate change may be additive or multiplicative; however, the answer remains largely uninvestigated (Dukes and Mooney 1999). One exception is Stachowicz et al. (2002) who found that the growth rate and recruitment of invasive sessile marine invertebrates was higher than native invertebrates at higher temperatures, suggesting that climate change facilitated invasive species introductions. Our study investigated how climate change and invasive species simultaneously affected nutrient uptake in Yellowstone Lake.

Ideally, time series data are used to tease apart the effects of invasive species and climate change; however, often data were not collected through time. To estimate how invasive species and climate change interact, we can use models. Models do not replace historical data, but they can be useful to estimate changes.

The introduction of lake trout (Salvelinus namaycush) in Yellowstone Lake provided an opportunity to investigate the combined effect of invasive species and climate change. Previous studies demonstrated that lake trout indirectly altered phytoplankton biomass in Yellowstone Lake (Tronstad 2008). However, the indirect effect of lake trout on phytoplankton uptake was unknown. Phytoplankton uptake had not previously been measured in Yellowstone Lake, therefore, past nitrogen demand by phytoplankton is unknown. However, using empirical relationships, and past water temperature and Secchi disk depths (measure of phytoplankton biomass), we estimated past phytoplankton uptake. Our objective was to quantify current phytoplankton uptake of nitrogen and estimate uptake in the past.

\section{Study Site}

Yellowstone Lake is located on the Yellowstone Plateau, Wyoming, which has a cold, continental climate with short summers and long winters (Felicetti et al. 2003). Yellowstone Lake is partially located within the Yellowstone caldera, an active silicic volcano (Morgan et al. 2003). Geology of the lake and surrounding basin is mainly rhyolite, with northern and eastern areas composed of andesite (Finn and Morgan 2002). Yellowstone Lake is mesotrophic (Kilham et al. 1996) and icecovered from December through May (Gresswell and Varley 1988). Yellowstone Lake is the largest high-elevation $(2357 \mathrm{~m})$ lake in North
America (Gresswell et al. 1997), with a surface area of $341 \mathrm{~km}^{2}$, shoreline length of $239 \mathrm{~km}$, and average depth of $43 \mathrm{~m}$ (Kaplinksi 1991). The lake is dimictic with summer stratification occurring from mid-July to mid-September with a deep $(\sim 20 \mathrm{~m})$ epilimnion. During the ice-free season, surface water temperatures vary between $3^{\circ} \mathrm{C}$ after ice-off and $18^{\circ} \mathrm{C}$ in mid-summer, dissolved oxygen ranges between 7 and $11 \mathrm{mg} / \mathrm{L}$, slightly basic $\mathrm{pH}$ (7.2 to 8.3$)$, and low water electrical conductivity (69 to $96 \mu \mathrm{S} / \mathrm{cm}$; J. Arnold, unpublished data).

Yellowstone Lake contained the largest remaining lacustrine population of Yellowstone cutthroat trout (Varley and Gresswell 1988), but their abundance fluctuated through time. The number of spawning cutthroat trout was low in the 1940s and 1950s due to egg-taking and liberal creel limits; however, the cutthroat trout population recovered after egg-taking ceased and stringent creel limits were imposed. The number of spawning cutthroat trout was high in the $1970 \mathrm{~s}$ and 1980s, averaging 48,000 fish spawning annually in Clear Creek, a tributary stream on the east side of Yellowstone Lake. The number of cutthroat trout peaked in 1978 when 70,105 fish spawned in Clear Creek. However, the abundance of cutthroat trout declined by $60 \%$ in Yellowstone Lake and $99 \%$ in Clear Creek since 1990 (Koel et al. 2005). Presently, indices of cutthroat trout abundance are the lowest on record.

Several fish species have been introduced in Yellowstone Lake, and longnose sucker (Catostomus catostomus), redside shiner (Richardsonius balteatus), lake chub (Couesius plumbeus), and lake trout (Salvelinus namaycush) have reproducing populations (Gresswell and Varley 1988, Gresswell et al. 1997). Lake trout are the only piscivorous fish in Yellowstone Lake. Even as young fish, only a small proportion of lake trout diet is zooplankton (Ruzycki et al. 2003) Lake trout were illegally introduced into Yellowstone Lake (Kaeding et al. 1996) in $~ 1985$ (Munro et al. 2005) and they eat $\sim 41$ cutthroat trout per year (Ruzycki et al. 2003). Lake trout are found throughout the water column after ice-out, but live primarily in the depths of Yellowstone Lake during summer. In fall, these fish spawn in shallow areas of Yellowstone Lake. The National Park Service (NPS) actively remove lake trout using gill nets, electrofishing, and a must kill angler restriction to reduce predation on native cutthroat trout 
(Koel et al. 2005). Between 1994 and 2006, the NPS removed $>198,000$ lake trout from the lake (Koel et al. 2007).

Other threats to cutthroat trout include whirling disease and drought. Whirling disease was discovered in 1998 and mainly affects young of the year cutthroat trout in certain spawning streams (Koel et al. 2006). For example, whirling disease has decimated the spawning run to Pelican Creek, a tributary with organic substrates that is preferred by the tubificid host, Tubifex tubifex (Krueger et al. 2006). Only $11 \%$ of cutthroat trout in Yellowstone Lake were infected with whirling disease (Koel et al. 2006). However, the number of spawning cutthroat trout has drastically declined in streams not affected by whirling disease. Therefore, we attributed the decline of cutthroat trout primarily to lake trout predation. On-going drought also affects young of the year cutthroat trout in small tributary streams by stranding individuals (Koel et al. 2005).

\section{$\downarrow$ METHODS}

To quantify the current demand for $\mathrm{NH}_{4}{ }^{+}$in Yellowstone Lake, we measured $\mathrm{NH}_{4}^{+}$ uptake by pelagic microbes (i.e., algae and bacteria). We estimated microbial $\mathrm{NH}_{4}^{+}$uptake by incubating ${ }^{15} \mathrm{NH}_{4} \mathrm{Cl}$ in $2.5 \mathrm{~L}$ Nalgene polycarbonate bottles for 3 hours in early June, late July, and early October 2005 . We collected water at 5,10 , and $15 \mathrm{~m}$ depths from 4 areas (South Arm, Southeast Arm, east of Stevenson Island, and West Thumb) of Yellowstone Lake ( 2 to 3 bottles per depth per site) and incubated bottles at their respective depths in northern Yellowstone Lake. To minimize uptake after incubations, we kept water samples dark and on ice. We collected phytoplankton by filtering 1.2 $\mathrm{L}$ of water through ashed 25-mm PALL type A/E glass fiber filters $(\sim 1 \mu \mathrm{m}$ pore size $)$ at 3 stages in the experiment: before adding ${ }^{15} \mathrm{NH}_{4}{ }^{+}$(ambient), immediately after adding ${ }^{15} \mathrm{NH}_{4}{ }^{+}(\mathrm{t}=0)$ and after 3 hours of incubating $(t=3 \mathrm{hr})$. Filters were rinsed with $60-\mathrm{mL}$ of deionized water after filtering microbes to remove excess ${ }^{15} \mathrm{~N}$ from filter. Samples were analyzed for $\delta^{15} \mathrm{~N}(\%)$ and the mass of $\mathrm{N}(\mu \mathrm{g})$ using Thermo-Finnigan Delta $^{\text {plus }}$ Advantage gas isotope-ratio mass spectrometer (Waltham, MA) interfaced with a
Costech Analytical ECS4010 elemental analyzer (Valencia, California) at the Colorado Plateau Stable Isotopes Laboratory in Flagstaff, Arizona.

To estimate $\mathrm{NH}_{4}^{+}$uptake by phytoplankton, we calculated the fraction of ${ }^{15} \mathrm{~N}$ in each sample $\left({ }^{15} \mathrm{~N} /\right.$ total $\mathrm{N}$; atomic fraction; $\mathrm{AF}$ ). The amount of ${ }^{15} \mathrm{~N}$ taken up during the incubation was calculated as the difference in $A F$ :

$$
A F_{x s}=A F_{t=3 h r}-A F_{t=0}
$$

where $A F_{x s}$ is the $A F$ excess, $A F_{t=3 h r}$ is the $\mathrm{AF}$ after 3 hours of incubating, and $A F_{t=0}$ is the $A F$ at time zero (sample taken immediately after ${ }^{15} \mathrm{~N}$ was added). Total ${ }^{15} \mathrm{~N}$ taken up $\left({ }^{15} N_{T U} ; \mu \mathrm{g} \mathrm{N} \mathrm{L}{ }^{-1}\right.$ $\mathrm{hr}^{-1}$ ) was calculated by:

${ }^{15} N_{T U}=\frac{N_{\text {filter }} \times A F_{x s}}{t \times v}$

where $N_{\text {filter }}$ is the amount of $\mathrm{N}$ on the filter $(\mu \mathrm{g})$, $t$ is the incubation time (hr), and $v$ is the volume of water filtered (L). The mass of ${ }^{15} \mathrm{~N}$ taken up $\left(\mathrm{M}_{\mathrm{TU}} ; \mu \mathrm{g} \mathrm{N} / \mathrm{L}\right)$ by microbes was calculated as:

$$
M_{T U}={ }^{15} N_{T U} \times t
$$

Mean concentration of ${ }^{15} \mathrm{~N}$ excess in the bottle

$$
\begin{aligned}
& \left(\bar{C}_{15} ; \mu \mathrm{g}^{15} \mathrm{~N} / \mathrm{L}\right) \text { was calculated as: } \\
& \bar{C}_{{ }^{15} N}=\frac{0.2-\left(0.2-M_{T U}\right)}{2}
\end{aligned}
$$

where $0.2 \mu \mathrm{g}{ }^{15} \mathrm{~N} / \mathrm{L}$ is the concentration added to each bottle. To calculate the turnover time for an $\mathrm{NH}_{4}{ }^{+}$molecule (TT; $\mathrm{hr}^{-1}$ ), we used:

$$
T T=\frac{{ }^{15} N_{T U}}{\bar{C}_{15}}
$$

We calculated phytoplankton $\mathrm{NH}_{4}{ }^{+}$uptake $(\mu \mathrm{g} \mathrm{N}$ $\mathrm{m}^{-3} \mathrm{hr}^{-1}$ ) by:

$$
U=T T \times C_{A} \times 1000
$$

where $\mathrm{C}_{\mathrm{A}}$ is the ambient concentration of $\mathrm{NH}_{4}^{+}$ $(\mu \mathrm{g} \mathrm{N} / \mathrm{L})$ in Yellowstone Lake water. In addition to microbial uptake, we measured Secchi disk depths $(\mathrm{m})$ at each site and water temperature $\left({ }^{\circ} \mathrm{C}\right)$ at the incubation site. 

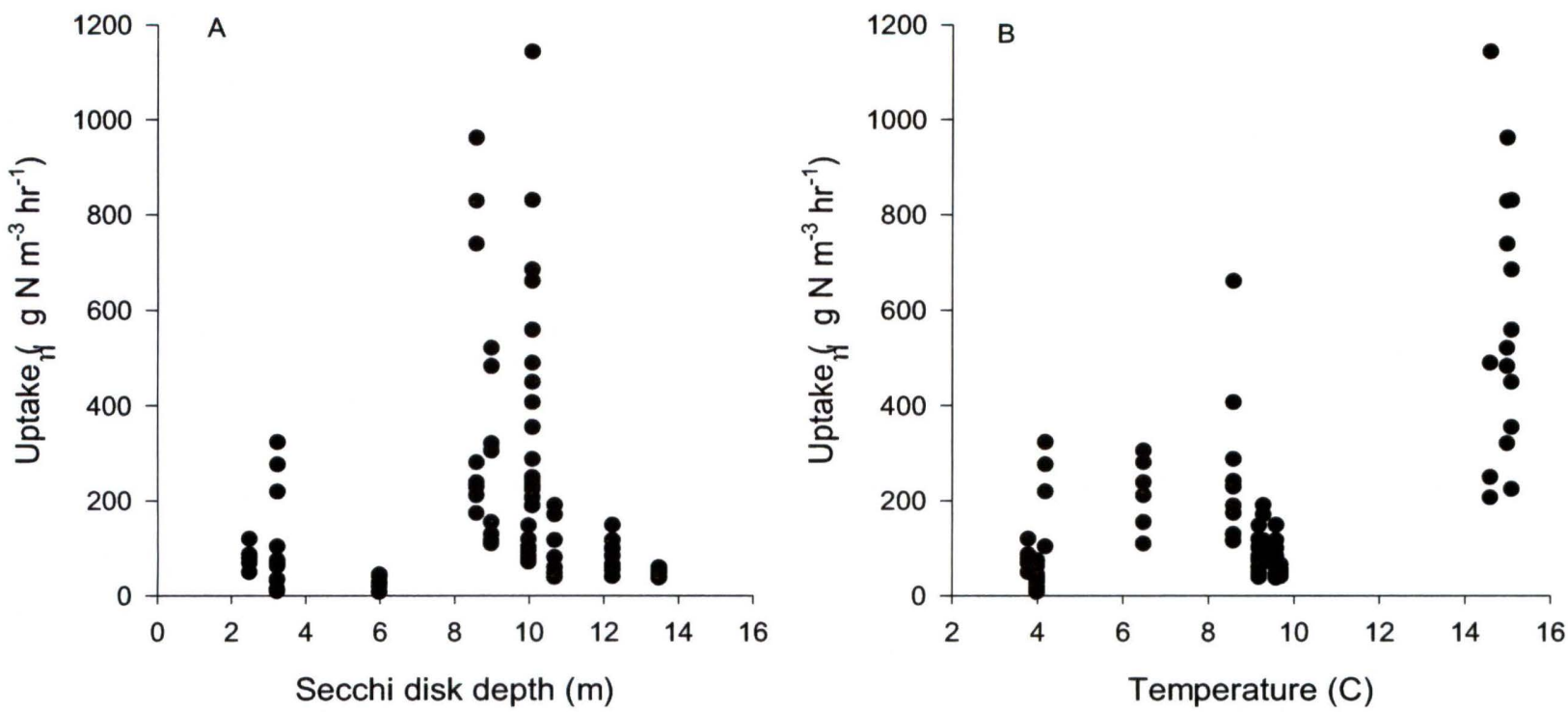

Fig. 1. A. Phytoplankton uptake $\left(\mu \mathrm{g} \mathrm{N} \mathrm{m}{ }^{-3} \mathrm{hr}^{-1}\right)$ was lower at deeper Secchi disk depths (m)

Fig. 1. B) Cooler water temperatures $\left({ }^{\circ} \mathrm{C}\right)$.

To estimate changes in past $\mathrm{NH}_{4}^{+}$ uptake in Yellowstone Lake, we modeled uptake using past Secchi disk depths and water temperatures recorded since 1976 using multiple regression. Secchi disk depths are an index of phytoplankton biomass in Yellowstone Lake (Tronstad 2008) and cutthroat trout indirectly affect phytoplankton biomass through cascading trophic interactions (Tronstad 2008). Temperature represented the effects of climate change on Yellowstone Lake. Because longterm data were available for these variables, we created relationships among Seechi disk depths, water temperature, and $\mathrm{NH}_{4}{ }^{+}$uptake from our 2005 measurements. To estimate past $\mathrm{NH}_{4}^{+}$ uptake, we used historical Seechi disk depths and water temperatures with our empirical relationships from 2005 .

\section{$\downarrow \quad$ RESULTS}

Pelagic microbes took up more $\mathrm{NH}_{4}{ }^{+}$in July $\left(8.1 \pm 1.9 \mathrm{mg} \mathrm{N} \mathrm{m}^{-2} \mathrm{hr}^{-1} ; 405 \pm 93 \mu \mathrm{g} \mathrm{N} \mathrm{m}^{-3}\right.$ $\left.\mathrm{hr}^{-1}\right)$, than June $\left(1.6 \pm 0.7 \mathrm{mg} \mathrm{N} \mathrm{m}^{-2} \mathrm{hr}^{-1} ; 81 \pm 34\right.$ $\left.\mu \mathrm{g} \mathrm{N} \mathrm{m}^{-3} \mathrm{hr}^{-1}\right)$ or October $\left(1.6 \pm 0.29 \mathrm{mg} \mathrm{N} \mathrm{m}^{-2}\right.$ $\mathrm{hr}^{-1} ; 82 \pm 15 \mu \mathrm{g} \mathrm{N} \mathrm{m}^{-3} \mathrm{hr}^{-1}$; Tukey's: $\left.\mathrm{p}<0.05\right)$ in 2005. Ammonium residence time was shortest in June $(9.7 \pm 3.9 \mathrm{hr})$ and July $(3 \pm 0.6 \mathrm{hr})$, and longest in October $(38 \pm 5.8 \mathrm{hr}$; Tukey's: p < $0.05)$. Because Secchi disk depths and water temperatures were collected in Yellowstone Lake since 1976, we formed empirical relationships between these variables and $\mathrm{NH}_{4}{ }^{+}$uptake in
2005. In 2005, deeper Secchi disk depths (SD; m) indicated lower $\mathrm{NH}_{4}{ }^{+}$uptake (Fig. 1A). Conversely, higher water temperatures $\left(\mathrm{T} ;{ }^{\circ} \mathrm{C}\right)$ suggested higher $\mathrm{NH}_{4}^{+}$uptake (Fig. 1B). Together, Secchi disk depth and water temperature explained $73 \%$ of the variation in $\mathrm{NH}_{4}^{+}$uptake $\left(\mathrm{N}_{\mathrm{TU}} ; \mu \mathrm{g} \mathrm{N} \mathrm{m}{ }^{-3} \mathrm{hr}^{-1}\right)$ measured in 2005

$\left(\ln N_{T U}=3.68+0.29 T-0.18 S D, t_{T}=11.6, \mathrm{t}_{S D}\right.$ $=-5.8, P<0.0001, \mathrm{df}=51)$.

We predicted past $\mathrm{NH}_{4}^{+}$uptake using the empirical relationship from 2005, and past surface water temperatures and Secchi disk depths (Theriot et. al. 1997; Jeff Arnold, unpublished data). Secchi disk depths have become $1.6 \mathrm{~m}$ deeper since 1976 (Fig. 2A), indicating lower phytoplankton biomass (Tronstad 2008). Lake temperatures increased $0.29^{\circ} \mathrm{C} /$ decade during the past 30 years (Fig. 2 B):

$$
T=-40+0.029 y-0.18 a-0.86 I+0.056 a \times I
$$

where $y$ is year (e.g., 1976), $a$ is days since August $10^{\text {th }}$, $\mathrm{I}$ is an indicator variable where 0 is on or before August $10^{\text {th }}$ and 1 is after August $10^{\text {th. }}$

$\mathrm{r}^{2}=0.87, \mathrm{df}=213, t_{y}=3.0, t_{a}=-33, t_{I}=-2.1$, $\left.t_{I \times a}=5.7, \mathrm{p}<0.001\right)$. Water temperature in Yellowstone Lake increased from ice-off to August $10^{\text {th }}$ and decreased thereafter, thus, we regressed inter-annual variation in water 
temperature as days since August $10^{\text {th }}$. Using these past data, the multiple regression model suggested that microbial uptake in Yellowstone Lake was similar from 1976 to $2005(\mathrm{t}=-0.06$, $\mathrm{df}=215, \mathrm{r}^{2}=0, \mathrm{p}=0.95$; Fig. 2C).

Ammonium uptake in Yellowstone Lake was comparable to $\mathrm{NH}_{4}^{+}$uptake in oligotrophic Flathead Lake, Montana (12.6 to $240 \mu \mathrm{g} \mathrm{N} \mathrm{m}^{-3} \mathrm{hr}^{-1}$; (Dodds et al. 1991). Pelagic microbes in Yellowstone Lake demanded less $\mathrm{NH}_{4}{ }^{+}$than an eutrophic Alaskan Lake (140 to $51,700 \mu \mathrm{g} \mathrm{N} \mathrm{m}^{-3} \mathrm{hr}^{-1}$; (Gu and Alexander 1993), and eutrophic Lake Balaton, Hungary (110 to $1560 \mu \mathrm{g} \mathrm{N} \mathrm{m}^{-3} \mathrm{hr}^{-1}$; (Presing et al. 2001).
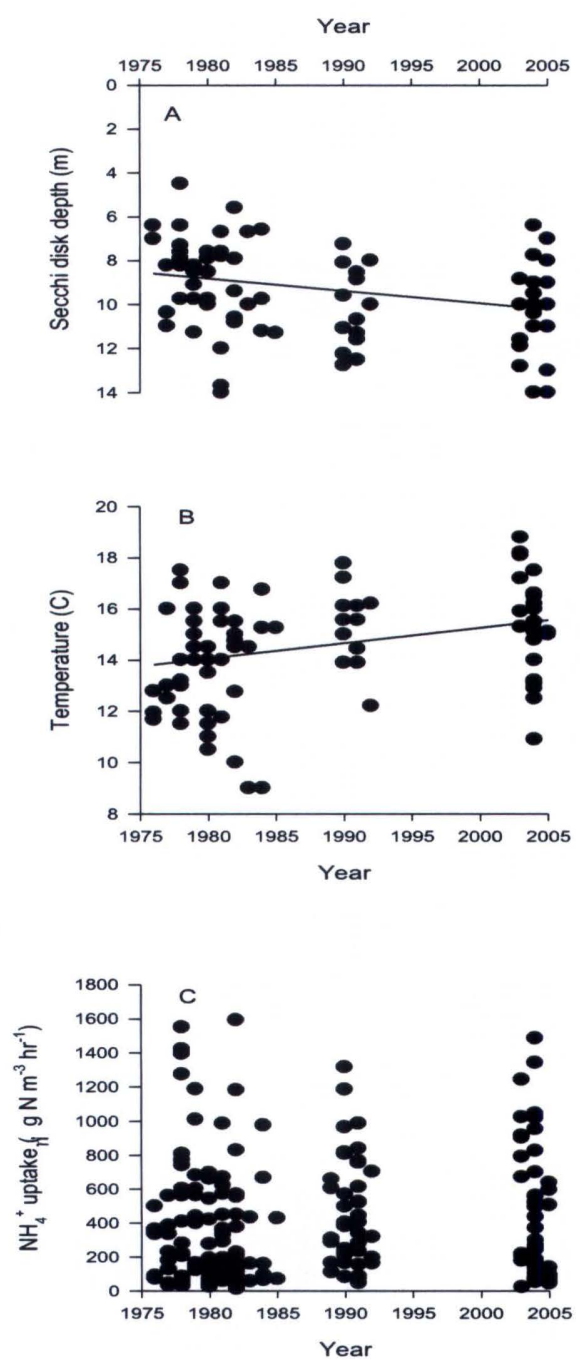

Fig. 2. A.) Secchi disk depths became $0.53 \mathrm{~m} /$ decade deeper and B.) water temperatures became 0.29 ${ }^{\circ} \mathrm{C} /$ decade warmer between 1976 and 2006. C.) Using the relationships in Fig. 1 and past data in A and B, our model suggested that phytoplankton uptake has not changed during the past 30 years.

\section{$\downarrow$ DISCUSSION}

Zooplankton excretion supplied the majority of $\mathrm{NH}_{4}{ }^{+}$demanded by phytoplankton in Yellowstone Lake; however, cutthroat trout excretion supplied a fraction of demand. In Yellowstone Lake, zooplankton excretion supplied $86 \%$ of the $\mathrm{NH}_{4}{ }^{+}$demanded by phytoplankton currently (Tronstad 2008). Our model suggested that phytoplankton uptake was similar between 1976 and 2006, thus zooplankton would have supplied $\sim 100 \%$ of the $\mathrm{NH}_{4}^{+}$demanded in the past. Cutthroat trout excretion supplied $0.23 \%$ of current demand. Assuming demand has not changed, cutthroat trout supplied $0.45 \%$ of past demand. Thus, comparing animal fluxes to nutrient demand is useful when estimating the importance of fluxes within the ecosystem.

The indirect effect of lake trout on phytoplankton was probably greater than their direct effect through changes in excretion fluxes. The introduction of lake trout facilitated a trophic cascade that lowered phytoplankton biomass (Tronstad 2008). Despite changes in excretion fluxes, native cutthroat trout excretion was a minor part of nutrient cycling in Yellowstone Lake. Our results were contrary to Glaholt and Vanni (2005) who reported that the direct effect of blue gill (Lepomis macrochirus) excretion was greater than their indirect effect on phytoplankton. Phytoplankton biomass indirectly decreased by $1 / 2$ to $1 / 9$ after the introduction of lake trout resulting in $1.6 \mathrm{~m}$ deeper Secchi disk measurements in Yellowstone Lake (Tronstad 2008). Similar to other lakes (e.g., Winder and Schindler 2004), climate changed increased water temperature by $0.29^{\circ} \mathrm{C} /$ decade in Yellowstone Lake. In our model, warmer water temperatures cancelled the effect of decreased phytoplankton biomass resulting in no change in modeled $\mathrm{NH}_{4}{ }^{+}$uptake in Yellowstone Lake. If we used temperature or Secchi disk depth alone to predict changes in uptake, we would have predicted higher and lower uptake, respectively.

\section{$\uparrow \quad$ CONCLUSIONS}

Climate change and invasive species can interact in surprising ways. Here, climate change and invasive species interacted additively resulting in no change in modeled $\mathrm{NH}_{4}{ }^{+}$uptake. 
Warmer water temperatures cancelled the effect of a sparser phytoplankton assemblage induced by invasive lake trout.

\section{$\downarrow$ Literature Cited}

Dodds, W.K., J.C. Priscu and B.K. Ellis. 1991. Seasonal uptake and regeneration of inorganic nitrogen and phosphorus in a large oligotrophic lake: sizefractionation and antibiotic treatment. Journal of Plankton Research 13:13391358.

Dukes, J. S. and H.A. Mooney. 1999. Does global change increase the success of biological invaders? Trends in Ecology \& Evolution 14:135-139.

Felicetti, L.A., C.C. Schwartz, R.O. Rye, M.A. Haroldson, K. A. Gunther, D. L. Philips and C. T. Robbins. 2003. Use of sulfur and nitrogen stable isotopes to determine the importance of whitebark pine nuts to Yellowstone grizzly bears. Canadian Journal of Zoology 81:763770 .

Finn, C., and L.A. Morgan. 2002. Highresolution aeromagnetic mapping of volcanic terrain, Yellowstone National Park. Journal of Volcanology and Geothermal Research 115:207-231.

Glaholt, S.P. and M.J. Vanni. 2005. Ecological responses to simulated benthic-derived nutrient subsidies mediated by omnivorous fish. Freshwater Biology 50:1864-1881.

Gresswell, R.E., W.J. Liss, G.L. Larson and P.J. Bartlein. 1997. Influence of basin-scale physical variables on life history characteristics of cutthroat trout in Yellowstone Lake. North American Journal of Fisheries Management 17:1046-1064.

Gresswell, R.E. and J.D. Varley. 1988. Effects of a century of human influence on the cutthroat trout of Yellowstone Lake. American Fisheries Society Symposium $4: 45-52$.
Gu, B., and V. Alexander. 1993. Seasonal variations in dissolved inorganic nitrogen utilization in a subartic Alaskan lake. Archiv Fur Hydrobiologie 126:273-288.

Kaeding, L.R., G.D. Boltz and D.G. Carty. 1996. Lake trout discovery in Yellowstone Lake threaten native cutthroat trout. Fisheries 21:16-20.

Kaplinksi, M.A. 1991. Geomorphology and geology of Yellowstone Lake, Yellowstone National Park, Wyoming. Master's thesis. Northern Arizona University, Flagstaff.

Kilham, S. S., E.C. Theriot, and S.C. Fritz. 1996. Linking planktonic diatoms and climate change in the large lakes of the Yellowstone ecosystem using resource theory. Limnology and Oceanography 41:1052-1062.

Koel, T. M., J. L. Arnold, P. Bigelow, P. D. Doepke, B. D. Ertel and M. E. Ruhl. 2007. Yellowstone Fisheries and Aquatic Sciences Annual Report for 2006. YCR-2007-04, National Park Service, Yellowstone Center for Resources, Yellowstone National Park, Wyoming.

Koel, T. M., P. Bigelow, P. D. Doepke, B. D. Ertel and D. L. Mahony. 2005. Nonnative lake trout result in Yellowstone cutthroat trout decline and impacts to bears and anglers. Fisheries 30:10-19.

Koel, T.M., D.L. Mahony, K.L. Kinnan, C. Rasmussen, C.J. Hudson, S. Murcia and B.L. Kerans. 2006. Myxobolus cerebralis in native cutthroat trout of the Yellowstone Lake ecosystem. Journal of Aquatic Animal Health 18:157-175.

Krueger, R.C., B.L. Kerans, E.R. Vincent and C. Rasmussen. 2006. Risk of Myxobolus cerebralis infection to rainbow trout in the Madison River, Montana, USA. Ecological Applications. 
Lonsdale, W.M. 1999. Global patterns of plant invasions and the concept of invasibility. Ecology 80:1522-1536.

Morgan, L.A., W.C. Shanks, D. Lovalvo, S.Y. Johnson, W.J. Stephenson, K.L. Pierce, S.S. Harlan, C.A. Finn, G. Lee, M. Webring, B. Schulze, J. Duhn, R. Sweeney and L. Balistrieri. 2003. Exploration and discovery in Yellowstone Lake: results from highresolution sonar imaging, seismic reflection profiling, and submersible studies. Journal of Volcanology and Geothermal Research 122:221-242.

Munro, A.R., T.E. McMahon and J.R. Ruzycki. 2005. Natural chemical markers identify source and date of introduction of an exotic species: lake trout (Salvelinus namaycush) in Yellowstone Lake. Canadian Journal of Fisheries and Aquatic Sciences 62:79-87.

Parmesan, C. and G. Yohe. 2003. A globally coherent fingerprint of climate change impacts across natural systems. Nature 421:37-42.

Presing, M., S. Herodek, T. Preston and L. Voros. 2001. Nitrogen uptake and the importance of internal nitrogen loading in Lake Balaton. Freshwater Biology 46:125-139.

Rahel, F.J. 2000. Homogenization of fish faunas across the United States. Science 288:854-856.

Randall, J.M. 2000. Improving management of nonnative invasive plants in wilderness and other natural areas. USDA Forest Service Proceedings 5:64-73.
Ruzycki, J.R., D.A. Beauchamp and D. L. Yule. 2003. Effects of introduced lake trout on native cutthroat trout in Yellowstone Lake. Ecological Applications 13:2337.

Stachowicz, J.J., J.R. Terwin, R.B. Whitlatch and R.W. Osman. 2002. Linking climate change and biological invasions: ocean warming facilitates nonindigenous species invasions. Proceedings of the National Academy of Science 99:15497-15500.

Theriot, E.C., S.C. Fritz and R.E. Gresswell. 1997. Long-term limnological data from the larger lakes of Yellowstone National Park, Wyoming, U.S.A. Artic and Alpine Research 29:304-314.

Tronstad, L. M. 2008. Ecosystem consequences of declining Yellowstone cutthroat trout on Yellowstone Lake and tributary spawning streams. Dissertation. University of Wyoming, Laramie.

Varley, J.D. and R.E. Gresswell. 1988. Ecology, status, and management of the Yellowstone cutthroat trout. American Fisheries Society Symposium 4:13-24.

Walther, G.R., E. Post, P. Convey, A. Menzel, C. Parmesan, T.J.C. Beebee, J.M. Fromentin, O. Hoegh-Guldberg and F. Bairlein. 2002. Ecological responses to recent climate change. Nature 416:389395.

Winder, M. and D. E. Schindler. 2004. Climate change uncouples trophic interactions in an aquatic ecosystem. Ecology 85:21002106. 